\section{Symposium Statement}

Two decades ago, in Spring I995, when the first issue of International Higher Education was published, no one had heard of MOOCs (massive open online courses), and much of the developing world still enrolled under Io percent of young people in higher education. The private revolution in higher education was not evident. Massification, already affecting much of the globe, was not fully understood. And the global knowledge economy was in its early stages. As a result of these and other forces, plus severe economic disruption caused by the Great Recession, postsecondary education has been profoundly affected during the past two decades.
Now, the implications of many of the trends just on the horizon two decades ago, are evident-and shaping the contemporary environment. There is talk about "creative disruption"-many in academe see it as just disruption. We have asked 25 experts, all of whom have had an association with International Higher Education and the Center for International Higher Education at Boston College, to reflect on a simple but profound question: What will be the most important challenge facing higher education in the coming two decades? This set of thoughtful mini-essays reflects some of the best global thinking on this theme.

Philip G. Altbach and Laura E. Rumbley

\section{Next Two Decades of Higher Education: A Developing Countries Perspective}

\section{Pawan Agarwal}

Pawan Agarwal is Joint Secretary, Ministry of Skill Development \& Entrepreneurship, and formerly Adviser (Higher Education), Planning Commission, Government of India. E-mail: pagarwal.dsde@gmail. com.

Higher education in developing countries has undergone major changes over the past two decades; the next two decades would be truly transformative. Changes are expected at all four levels: within the classrooms, inside higher education institutions, in nation states, and at the global level.

Classrooms for the future would be based on a new learning paradigm. Focus will shift from content to pedagogy with technology and learning analytics playing a key role. Impact of technology on classroom instruction has thus far been marginal, but will be profound in the next two decades. Even with large class sizes, instruction will be customized to individual needs and preferences. Students will increasingly be engaged in experiential and interactive learning, learning from themselves, their peers, and their immediate environment-just as much as they would from their professors.

In terms of institutions, there would be a far larger number of players. Monopoly power of universities on knowledge creation and dissemination would be significantly diluted as a diverse set of nonuniversity actors emerge on the horizon. Moreover, the distinction between for-profit and nonprofit entities would get blurred. There will be an unbundling of functions of universities, with the focus on core functions of teaching and research. For most universities, a shift from the collegial to a managerial atmosphere is inevitable.

Higher education systems are at different stages of development in various countries. While most advanced nations have matured and fully developed systems with universal enrollment, developing nations have seen a dramatic expansion, primarily driven by the private sector, over the past two decades. The next two decades would be focused on consolidation and quality improvement instead of further expansion. With increasing cost pressures, there will be a convergence of national policies to pass on the costs of higher education to students and parents. Online platforms and learning will lead to democratization of knowledge and provide near universal access to higher education, even in the remotest areas and to the disadvantaged sections. While actual quality differentials would be much less, there would be more intense competition for top institutions especially in reputation and perception.

Higher education would be far more global in its scale and scope than today but with some difference. Today, perceived winners are those countries that are able to attract a large number of students to their home campuses or establish international branch campuses. However, it will be recognized that this is not a zero sum game, but all countries, even those countries that have outbound students of higher education tend to benefit through access to high-quality education.

With deepening global economic and cultural conditions and increased use of digital technologies, global networking and a participatory learning process will emerge with transnational education playing an important part. The present trend of cross-border mobility of students for full course of study would be replaced by part study abroad through semester exchanges, etc.

Overall, these developments would have positive consequences for higher education, but some negative implica- 
tions cannot be ruled out. The next two decades would lay the foundations, on which higher education would evolve in the developing world for the many decades to come after.

\section{Massification and the Global Knowledge Economy: The Continuing Contradiction}

\section{Philip G. Altbach}

Philip G. Altbach is research professor and director of the Center for International Higher Education at Boston College.E-mail: altbach@ bc.edu.

Two of the challenges of the past half century will continue to be among the key drivers of higher education realities, for the coming several decades-providing greater access to tertiary education and sustaining research centers that will contribute and disseminate the knowledge essential to modern societies. These two key forces are contradictory and pull academe in different directions.

Global enrollments now stand at more than 150 million, having doubled in just a few decades, and it is likely that there will be another 100 million added by 2020 . A significant part of that growth will be in just two countriesChina and India. Providing postsecondary education to larger segments of the population is not only necessary, as increasingly sophisticated economies demand higher levels of training, but as key to social mobility and more attractive employment.

Massification has placed great stress on government finances and has led to a rapidly growing private higher education sector. Shortages of qualified academic staff and newer, underresourced institutions often accompany this rapid expansion; as a consequence, overall quality has declined, in some countries dramatically. Yet, many millions have now obtained academic qualifications and in general achieved better lives as a result.

At the same time, the global knowledge economy requires more sophisticated and top-quality higher education to educate graduates who are capable of participating in the globalized 2Ist century economy. Universities must support research in the pursuit of new scientific endeavors, as well as serve as repositories of knowledge in all disciplines. Research universities, the engines of the global knowledge economy, are complex institutions, and are the foci of international networks. Although powerful, they are also fragile institutions, requiring autonomy, shared governance, and academic freedom. These universities are expensive and complex. They are, with few exceptions, public institutions requiring unqualified state support; these are the worldclass universities that dominate the rankings. Yet, it is often difficult for governments to understand these expensive yet necessary universities.

There is a seeming dichotomy between the necessity of providing postsecondary education for large numbers of students and, at the same time, supporting elite research universities. Yet, both are necessary parts of a differentiated academic system, and both serve important functions in the global knowledge economy-one to provide the increasingly sophisticated needs of the economy, as well as the general knowledge to function as effective citizens, and the other to educate the most able students, to provide both basic and applied research. Both are absolutely essential to a successful national economy, as well.

Supporting these two-core objectives is a necessity for the coming decades. Yet, there are signs in many countries, mass "demand absorbing" higher education is proving too heavy a burden for governments. Also, a growing private sector, often for-profit, tends to fill the gap, often providing lower-quality education. At the same time, expensive and largely public research universities are confronting alarming budget cuts. A key challenge is to ensure that both key aspects of higher education are appropriately supported.

\section{The Crisis of the Public Mis- sion in Higher Education}

\section{JORGE BALÁn}

Jorge Balán is senior research scholar, Columbia University. E-mail: jb3369@columbia.edu.

The major challenge for higher education worldwide is to strengthen and revitalize its commitment to the public mission, as a response to the overall-per-student decline in public funding, the shifting rationale, strategies, and instruments that governments subsidize and regulate higher education, and to cope with changes in student demand and in the society at large.

State ownership and funding of public institutions are often and erroneously identified with a public mission in countries where these institutions enjoy considerable prestige, autonomy, and political clout in shaping public policy. Administrators, faculty, and students are often critical of the 